УДК 159.9.019.4:001.8(045)

DOI https://doi.org/10.26661/2310-4368/2021-1-13

\title{
ОСОБЛИВОСТІ ОСОБИСТІСНИХ І ГРУПОВИХ БАЗОВИХ ПОТРЕБ СТУДЕНТІВ-ПСИХОЛОГІВ
}

\author{
Миколенко Н. В. \\ старший викладач кафедри практичної психології \\ Київський університет імені Бориса Грінченка \\ вул. Бульварно-Кудрявська, 18/2, Київ, Україна \\ orcid.org/ 0000-0002-1438-6034 \\ n.mykolenko@kubg.edu.ua
}

Ключові слова: потреба, мотивачія, професійна підготовка, базові потреби, особистісний розвиток, самовираження.
У статті наведено результати дослідження актуальності базових потреб студентів-психологів, що завершують навчання на бакалавраті. Здійснено аналіз наявних досліджень, об’єктом яких є аналіз потреб студентів ЗВО, зроблено висновок про їх фрагментарний характер, а також відсутність робіт, присвячених мотивації студентів-психологів. Обгрунтовано важливість вивчення системи потреб студентів для забезпечення найкращих умов для їх особистісного розвитку та професійної підготовки, формування їх готовності до майбутньої професійної діяльності. 3'ясовано, що термін «базові потреби» не є чітко окресленим.

Дослідження грунтується на класифікації базових потреб за А. Маслоу. Як діагностичний інструментарій використано методику «Потреби» (метод парних порівнянь) В.В. Скворцова; для статистичної обробки результатів було застосовано Т-критерій Стьюдента та кластерний аналіз. Вибірку склали 60 студентів IV курсу спеціальності «Психологія» (30 денної та 30 заочної форми навчання). Встановлено, що домінуючою групою потреб студентів-психологів IV курсу є потреби у самореалізації, а найменш актуальною - потреби у безпеці. Визначено найменш задоволені (потреби у самореалізаціі) та найбільш задоволені (соціальні міжособистісні) потреби студентів. Здійснено порівняльний аналіз студентів денної та заочної форми навчання, результатом якого $€$ висновок про порівняно більшу вираженість потреб у самовираженні студентів заочної форми та більшу вираженість потреб у безпеці студентів денної форми навчання.

За допомогою кластерного аналізу виділено три кластери досліджуваних, найбільшим із яких є студенти з актуальними потребами вищого рівня в термінах теорії мотивації А. Маслоу. Сформульовано загальні рекомендації щодо створення умов для самовираження студентів у навчальному процесі. Серед подальших перспектив вивчення цієї проблеми зазначено перегляд та рестандартизацію методики «Потреби» В.В. Скворцова і проведення порівняльних досліджень, а також вивчення за допомогою діагностики групових потреб особливостей академічної студентської групи. 


\title{
FEATURES OF PERSONAL AND GROUP BASIC NEEDS OF PSYCHOLOGY STUDENTS
}

\author{
Mykolenko N. V. \\ Assistant Professor at the Department of Practical Psychology \\ Borys Grinchenko Kyiv University \\ Bulvarno-Kudriavska str., 18/2, Kyiv, Ukraine \\ orcid.org/0000-0002-1438-6034 \\ n.mykolenko@kubg.edu.ua
}

Key words: need, motivation, professional training, basic needs, personal development, selfactualization.
The article provides findings of the study of the relevance of basic needs of psychology students who are about to complete a Bachelor's program. The author analyses the available studies, the object of which is the analysis of HEI students, concludes about their fragmentary nature and a lack of papers devoted to the motivation of psychology students. It is substantiated the importance of elucidating a system of students' needs to ensure the best conditions for their personal development and professional training, formation of their readiness for future professional activity. The author has found out the term "basic needs" is vague.

The research is based on the classification of basic needs according to A. Maslow. Diagnostic tools have consisted of methodology "Needs" (a method of pair comparisons) by V.V. Skvortsov; Student's t-test for a statistical processing of findings, and cluster analysis. A sample has involved 60 undergraduate students of the specialty "Psychology" (30 intramural students and 30 extramural students). It is established that a predominant group of needs of undergraduate psychology students includes a self-actualization need, and the least relevant one is a safety need. The author has identified the least satisfied (self-realization needs) and the most satisfied (social inter-personal) student needs. There has been a comparison of the intramural and extramural students; it has resulted in the conclusion about a comparatively higher manifestation of the self-actualization needs of extramural students and a higher manifestation of the safety needs of intramural students.

Using cluster analysis, the author has distinguished three clusters of study participants - the biggest of them is students who have actual needs of the supreme level in the meaning of A. Maslow's motivation theory. General recommendations for creating conditions for students' self-actualization in the educational process have been formulated. The further prospects of the study of this problem involve reconsidering and re-standardizing methodology "Needs" by V.V. Skvortsov, conducting comparative studies, studying the features of an academic student group through the diagnostics of group needs.
Постановка проблеми. Сучасна освіта має відповідати потребам як суспільства, так і запитам здобувачів освіти. Педагогічна стратегія вищого навчального закладу в ідеалі має бути побудована з урахуванням аналізу потреб студентів, який би дозволив зробити процес підготовки фахівця відповідним за змістом і задачами його майбутній професійної діяльності, а також таким, що створює сприятливі умови для їх особистісного розвитку та психологічного благополуччя. Особливо це стосується підготовки фахівців професій типу «людина-людина», у яких особистість фахівця виступає інструментом впливу, і найбіль- шою мірою - підготовки майбутніх психологів. Оскільки діяльність психолога-практика передбачає не лише набуття професійної компетентності, але й особистісну підготовку, ступінь задоволеності особистісних потреб майбутнього фахівця може мати значний вплив на його готовність до здійснення професійної діяльності, до надання допомоги іншим.

Проблематика вивчення системи потреб студентів є об'єктом скоріше періодичного, аніж постійного інтересу науковців. Значна кількість робіт присвячена вивченню здебільшого окремих потреб або тематичних груп потреб студентів, 
наприклад, пізнавальних, інформаційно-освітніх, потреби у додатковій освіті.

Вивченню системи потреб студентів присвячені дослідження вітчизняних вчених В.I. Майковської, Г.I. Гончар та деяких зарубіжних дослідників. В.І. Майковська [1] розглядає потреби студентів як основу мотивації у професійні підготовці фахівців і як фактор управління якістю цієї підготовки. На її думку, мотивування до навчання має спиратися на задоволення потреб студента таким шляхом, який сприятиме досягненню цілей професійної підготовки. Дослідження Г.I. Гончар [2] розкриває динаміку мотиваційно-потребової сфери від I до IV курсу студентів спеціальності «Фізичне виховання», iii зв'язок з якістю професійної підготовки та розробляє організаційно-педагогічні умови іiі формування, експериментально підтверджує ii1 результативність.

У роботах Е.Г. Щебельської, М.В. Большедворської та Є.О. Соловьової, Т.Н. Рандовцевої й інших $[3 ; 4 ; 5 ; 6 ; 7]$ досліджуються базові потреби студентів. Саме поняття «базових (основних) потреб» не є чітко окресленим науковим терміном. Воно походить із теорії мотивації А. Маслоу $\mathrm{i}$, попри існуючі інші способи розуміння базових потреб як вроджених або найактуальніших, до цього використовується здебільшого стосовно виділених А. Маслоу 5 груп потреб [8]. Ідея про три вроджені базові потреби (автономії, компетенції та приналежності) лежить в основі іншої концепції - теорії самодетермінації Е. Дісі та Р. Раяна [9], але існуючі нечисленні дослідження потреб у рамках цієї відносно «молодої» теорії стосуються лише дорослих.

Досліджуючи ступінь задоволення основних потреб першокурсників, Е.Г. Щебельська наголошує на системному характері потреб студентів і підіймає проблему культури потреб. Необхідність iii формування у педагогічному процесі зумовлена тим, що виховання, «прищеплення» потреб $\epsilon$ шляхом формування свідомості та загальної культури здобувачів вищої освіти [3]. Порівнюючи між собою картини потреб студентів двох вузів, Т.Н. Рандовцева доходить висновку про відсутність значущих відмінностей між ними і розробляс рекомендації щодо організації навчального процесу з метою задоволення пріоритетних потреб студентів [4].

Проаналізувавши низку робіт з цієї проблеми, можна підсумувати, що попри зазначену авторами iii важливість для скерування особистісного розвитку та професійної підготовки майбутніх фахівців, ці дослідження мають досить фрагментарний характер. У розглянутих роботах констатуються або (рідше) порівнюються між собою результати досліджень студентів різних курсів, закладів, спеціальностей, а отримані у кожному випадку результати, очевидно, залежать як від етапу навчання та напряму освіти, так і від конкретних культурно-історичних умов і не дозволяють прослідкувати якісь тенденції.

Потреби студентів, які навчаються за спеціальністю «Психологія», ще не ставали об'єктом вивчення. Крім того, існує певна суперечливість у тлумаченні домінуючих за результатами тих чи інших досліджень потреб - з одного боку як фрустрованих і таких, що потребують уваги і сприяння та створення умов для їх задоволення з боку закладу освіти, а 3 іншого - як таких, що визначають спрямованість особистості, впливають на іiі професійний саморозвиток.

Метою нашої роботи є дослідження актуальності базових потреб студентів-психологів, які завершують навчання на бакалавраті.

Потреба $є$ станом необхідності у чомусь, i ця необхідність мотивує особу на пошук і здобування необхідного. Крім сигнальної та спонукальної функцій, потреба відіграє також пізнавальну, оцінну та світоглядну. Тобто предмет потреби пізнається в процесі іiі задоволення; крізь призму потреби відбувається оцінка предметів, явищ, послуг, діяльності; характер потреб визначає світогляд і спосіб життя особистості та групи [10]. Отже, дослідження актуальності базових потреб студентів-психологів у першому семестрі 4-го курсу важливе і для розуміння особливостей світогляду майбутніх колег, якості їх особистісної підготовки, і з точки зору можливої корекції навчально-виховних впливів, сприяння їх реалізації.

У дослідженні взяли участь 60 студентів IV курсу спеціальності «Психологія» (30 денної та 30 заочної форми навчання) КУБГ. Дослідження було проведене за допомогою методики «Потреби» (метод парних порівнянь) В.В. Скворцова [11], відомої здебільшого під назвою «Оцінка ступеня задоволеності основних потреб» (як варіант - «Діагностика особистісних і групових базових потреб»). Методика побудована на класифікації базових потреб А. Маслоу із заміною змісту та обсягу поняття «фізіологічні потреби» на «матеріальні потреби» і виявляє відносну задоволеність одних потреб порівняно з іншими.

Отримані результати виявили переважання потреби у самовираженні (вона є домінуючою у $36,7 \%$ досліджуваних), тобто потреби розвивати свої сили і здібності, прагнути до нового і незвіданого та займатися справою, що вимагає повної віддачі. За нею йдуть потреби у визнанні та матеріальні потреби (24,2\% і 23,3\% відповідно). Найнижчий відсоток досліджуваних - із пріоритетом соціальних міжособистісних потреб і потреб у безпеці (12,5\% і 3,3\% відповідно) (рис. 1). 


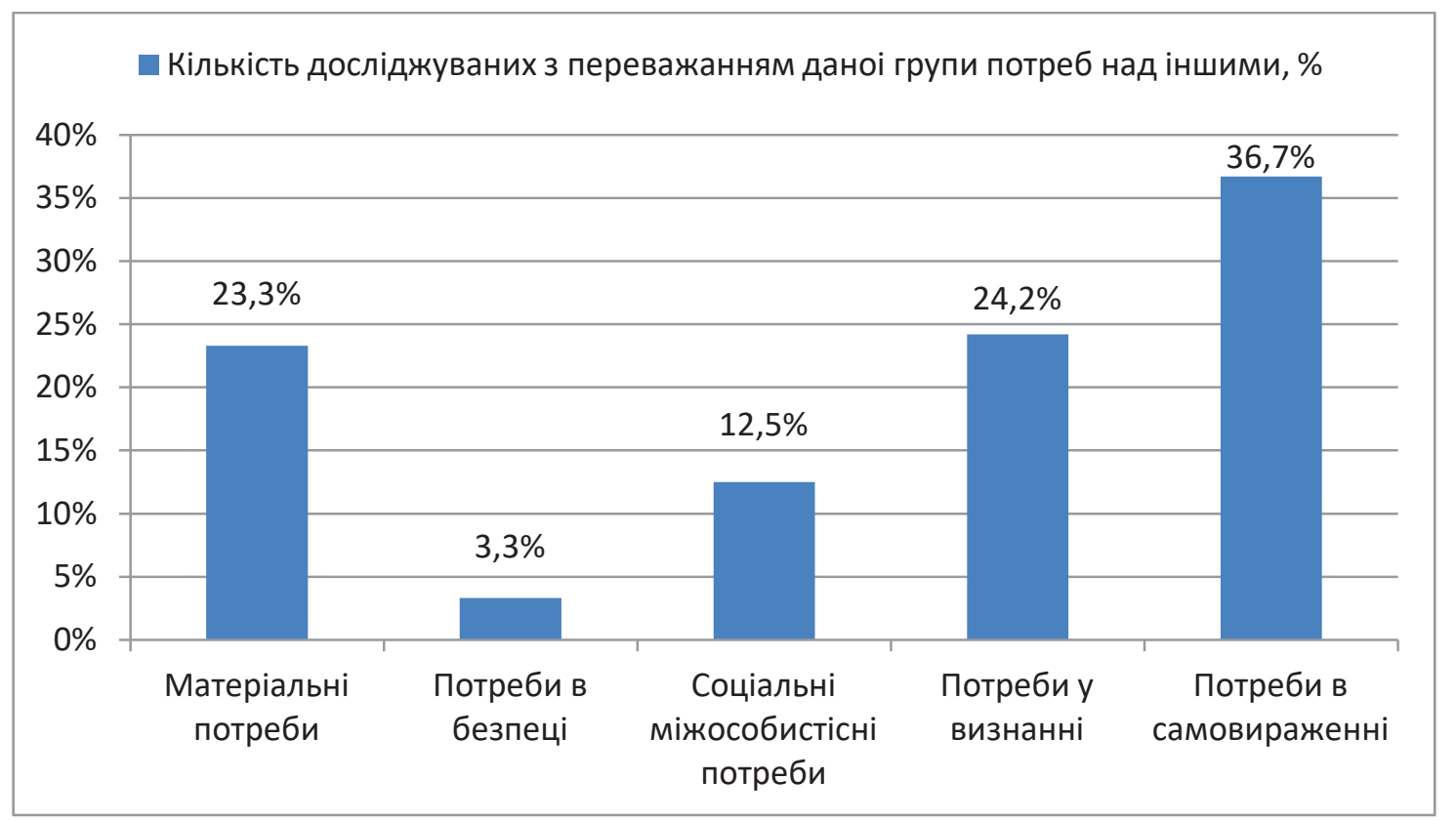

Рис. 1. Пріоритетність потреб студентів-психологів IV курсу

Серед досліджуваних лише у 8,3\% потреба у самовираженні за балами відповідає рівню повної задоволеності, 66,7\% мають частково задоволену потребу у самовираженні, а $25 \%$ - повністю незадоволену. Пріоритетність потреби у самовираженні є результатом, аналогічних якому ми не спостерігали при проведенні аналізу досліджень 3 цієї проблематики. Він може пояснюватися багатьма факторами, зокрема заключним етапом професійної підготовки, тривогою стосовно можливостей професійної і не тільки реалізації після закінчення навчання; специфікою напряму підготовки, який орієнтує студентів-психологів на постійний особистісний розвиток як вимогу професії до фахівця; ситуативним обмеженням можливостей самореалізації в умовах пандемії COVID-19 тощо.

Інші результати розподілу досліджуваних за ступенем відносної задоволеності потреб представлені у табл. 1. 3 таблиці, зокрема, видно, що найбільш благополучною 3 точки зору задоволення є соціальні міжособистісні потреби (мати теплі відносини з людьми, мати хороших співрозмовників, бути зрозумілим іншим). Очевидно, що це пов'язано саме зі специфікою напряму підготовки, оскільки спілкування та побудова стосунків із людьми є основною діяльністю практичного психолога і може бути одним із показників психологічної готовності студентів IV курсу до здійснення професійної діяльності.

Результати дослідження містять також цікавий розподіл пріоритетності категорій, що входять до кожної з групи потреб (рис. 2). Так, перші 4 місця за середніми балами займають категорії № 7 «Розвивати свої сили і здібності», № 9 «Підвищувати рівень майстерності і компетентності», № 8 «Забезпечити собі матеріальний комфорт» і № 3 «Забезпечити собі майбутнє», що входять до груп потреб у самовираженні, визнанні, матеріальних благах і у безпеці. Найменш пріоритетною виявилася категорія № 10 «Уникати неприємностей» із групи потреб у безпеці та № 1 «Домогтися визнання і поваги» 3 потреб у визнанні. Отже, очікуваного за логікою переважання категорій однієї групи над категоріями іншої не відбувається. Категорія № 3, яка входить до найменш пріоритетної групи потреб у безпеці, отримала високе середнє значення, а категорія № 14 «Займатися справою, що вимагає повної віддачі», входячи до домінуючої групи, має досить низьке середнє значення.

3 іншого боку, низькі середні значення деяких категорій пояснюються їх не актуальним для нинішньої молоді змістом. Спонукання «Уникати неприємностей» неактуальне через недосяжність через швидкий темп і непередбачуваність стилю сучасного життя, а також через кризовий стан ситуації у країні. «Займатися справою, що вимагає повної віддачі» нині означає багато працювати, не маючи достатньо часу на себе і не обов'язково при цьому отримувати за це достатню винагороду. «Заробляти на життя» також асоціюється із низьким заробітком, що дається непросто. Це наводить на думку, що методика потребує перегляду та оновлення.

Порівняння вибірок студентів денної та заочної форм навчання за Т-критерієм Стьюдента показало значні відмінності у показниках «Потреба у 
Таблиця 1

Відносна задоволеність потреб студентів-психологів IV курсу

\begin{tabular}{|l|c|c|c|c|c|}
\hline $\begin{array}{c}\text { Рівень задоволен- } \\
\text { ня потреб }\end{array}$ & $\begin{array}{c}\text { Матеріальні } \\
\text { потреби }\end{array}$ & $\begin{array}{c}\text { Потреби в } \\
\text { безпеці }\end{array}$ & $\begin{array}{c}\text { Соціальні } \\
\text { міжособистісні } \\
\text { потреби }\end{array}$ & $\begin{array}{c}\text { Потреби у } \\
\text { визнанні }\end{array}$ & $\begin{array}{c}\text { Потреби в само- } \\
\text { вираженні }\end{array}$ \\
\hline $\begin{array}{l}\text { Зона незадоволе- } \\
\text { ності }\end{array}$ & $16,7 \%$ & $3,3 \%$ & $3,3 \%$ & $13,3 \%$ & $25 \%$ \\
\hline $\begin{array}{l}\text { Зона часткової } \\
\text { задоволеності }\end{array}$ & $71,7 \%$ & $56,7 \%$ & $66,7 \%$ & $81,7 \%$ & $66,7 \%$ \\
\hline Зона задоволеності & $11,7 \%$ & $23,3 \%$ & $30 \%$ & $5 \%$ & $8,3 \%$ \\
\hline
\end{tabular}

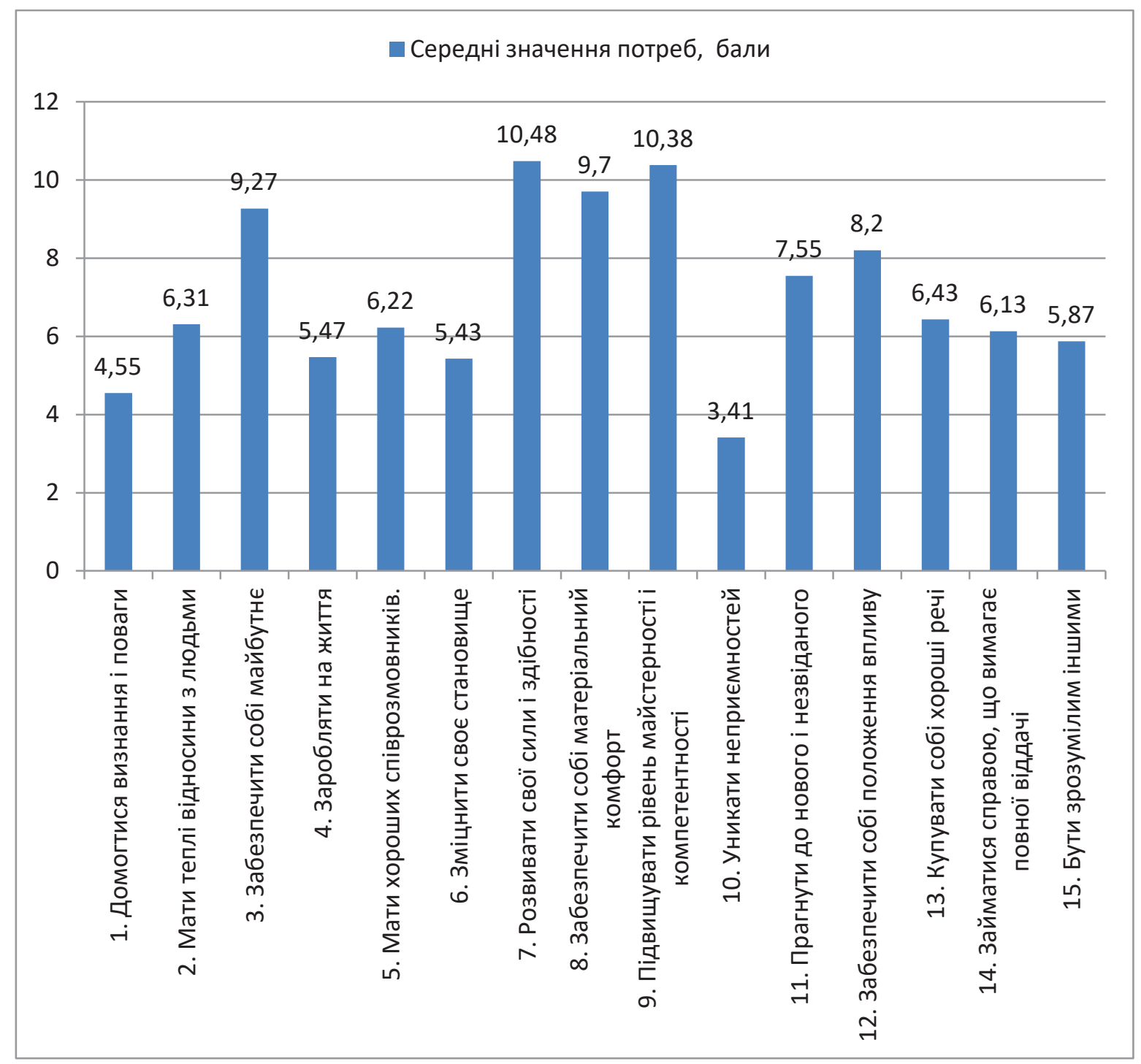

Рис. 2. Пріоритетність деталізованих потреб студентів-психологів IV курсу

самовираженні» та «Потреба у безпеці». Потреба у самовираженні є більш пріоритетною для студентів заочної форми навчання, ймовірно, через брак сфер і діяльностей, в яких можна було задовольнити потребу у самовираженні. На відміну від студентів денної форми, на момент прове- дення дослідження вони не були активно залучені до навчального процесу, при цьому частина 3 них в силу різних обставин не має постійної зайнятості на роботі. Потреби у безпеці (забезпечити собі майбутнє, зміцнити своє становище, уникати неприємностей) виявилися дещо більш актуаль- 
ними для денної форми навчання, що зумовлено більшою невизначеністю їх життєвої ситуації напередодні завершення навчання - діяльності, яка була основною для них протягом кількох років. Щодо інших показників, то закономірних відмінностей не знайдено. Результати порівняння середніх значень представлені у табл. 2.

Як видно 3 таблиці, розсіювання значень $є$ найбільшим у показниках «Потреби в самовираженні» для обох форм навчання, «Матеріальні потреби» для денної форми навчання та «Соціальні міжособистісні потреби» - для заочної форми навчання.

3 метою виділення у виборці груп, більш-менш однорідних за показниками актуальності тих чи інших потреб, було здійснено кластерний аналіз отриманих даних. У результаті виокремлено три різномісні кластери (групи досліджуваних). У перший (найбільший) кластер увійшли 38 студентів (23 денної і 17 заочної форми навчання), для яких притаманне переважання потреби у самовираженні (середнє 26,3 балів) та визнанні (25,1 балів). Попри те, що теорія ієрархічної побудови потреб не підтвердилася у повній мірі, отримана нами картина наводить на думку, що до цього кластеру увійшли досліджувані, зовнішні умови яких виявилися максимально сприятливими, що дозволило їм задовольнити нижчі за рівнем потреби, а вищі вийшли на передній план.

У другий за розміром кластер увійшло 13 осіб (7 осіб денної і 6 заочної форми навчання) із вираженим домінуванням соціальних міжособистісних потреб та актуальними потребами у самовираженні. До третього кластеру, що складається із 9 осіб, увійшло 8 студентів заочної та 1 студент денної форми навчання. Для цього кластеру притаманно домінування матеріальних потреб і потреби у безпеці. Цілком логічно припустити, що до неї потрапили студенти, які на момент проведення дослідження відчували матеріальні труднощі.

Висновки. У цьому дослідженні ми встановили, що найактуальнішою потребою студентів IV курсу спеціальності «Психологія» КУБГ $є$ потреба у самовираженні, конкретизована в категорії розвитку своїх сил і здібностей, а найменш актуальною - потреба у безпеці. Саме ці дві групи потреб дають значимі розбіжності при порівнянні студентів денної та заочної форм навчання. Найбільш задоволеними серед всієї сукупності досліджуваних виявилися соціальні міжособистісні потреби. Серед досліджуваних був виділений i кластер тих, у кого ці потреби виступають домінуючими. 63,3\% досліджуваних увійшли у кластер, для якого характерна актуальність потреб вищого, в розумінні теорії ієрархії потреб А. Маслоу, рівня.

У дослідженні взяли участь студенти 4 різних академічних груп, які виразно відрізняються між собою способами спілкування та діяльності. Інтерес до цих відмінностей від початку і підштовхнув нас до проведення цього дослідження. На жаль, замала та неоднакова по академічних групах кількість досліджуваних не дає нам можливості обговорювати отримані результати в цій роботі, але виразні тенденції, що співвідносяться i3 результатами спостереження дають підстави вважати, що дослідження актуальності групових базових потреб може допомогти у розумінні своєрідності окремої академічної групи.

3 огляду на отримані результати напрошуються дуже загальні рекомендації щодо ще більшого урізноманітнення навчального процесу на IV курсі, надання студентам ще більших можливостей пробувати себе в різних видах діяльності, пов'язаних iз фаховою підготовкою, брати учать у різних проектах, виступаючи при цьому у різних ролях.

Перспективу подальших досліджень ми бачимо у перевірці та рестандартизації методики

Таблиця 2

Порівняння середніх значень денної та заочної форм навчання за Т-критерісм Стьюдента

\begin{tabular}{|l|l|c|c|}
\hline \multicolumn{1}{|c|}{ Види потреб } & Форма навчання & Середнс & $\begin{array}{c}\text { Середньоквадратичне } \\
\text { відхилення }\end{array}$ \\
\hline \multirow{2}{*}{ Потреби у самовираженні } & денна & $21,9 *$ & 7,34 \\
\cline { 2 - 4 } & заочна & $26,0 *$ & 5,56 \\
\hline \multirow{2}{*}{ Потреби у визнанні } & денна & 21,4 & 5,16 \\
\cline { 2 - 4 } & заочна & 23,1 & 5,90 \\
\hline \multirow{2}{*}{ Соціальні міжособистісні потреби } & денна & 19,1 & 6,58 \\
\cline { 2 - 4 } & заочна & 18,2 & 5,25 \\
\hline \multirow{2}{*}{ Потреби в безпеці } & денна & $20,2 *$ & 4,33 \\
\cline { 2 - 4 } & заочна & $16,3 *$ & 7,19 \\
\hline \multirow{2}{*}{ Матеріальні потреби } & денна & 23,2 & 5,18 \\
\cline { 2 - 4 } & заочна & 21,2 & \\
\hline
\end{tabular}

*-значимі відмінності в показниках 
Таблиця 3

Показники актуальності потреб для кожного кластеру досліджуваних

\begin{tabular}{|c|c|c|c|c|c|c|}
\hline Кластери & $\begin{array}{l}\text { К-ть } \\
\text { осіб }\end{array}$ & $\begin{array}{c}\text { Матеріальні } \\
\text { потреби }\end{array}$ & $\begin{array}{c}\text { Потреби в } \\
\text { безпеці }\end{array}$ & $\begin{array}{l}\text { Соціальні мі- } \\
\text { жособистісні } \\
\text { потреби }\end{array}$ & $\begin{array}{c}\text { Потреби у } \\
\text { визнанні }\end{array}$ & $\begin{array}{l}\text { Потреби в са- } \\
\text { мовираженні }\end{array}$ \\
\hline $\begin{array}{l}\text { № 1, середнє } \\
\text { станд. відхилення }\end{array}$ & 38 & $\begin{array}{l}21,4 \\
4,21\end{array}$ & $\begin{array}{l}17,1 \\
4,75\end{array}$ & $\begin{array}{l}15,5 \\
3,24\end{array}$ & $\begin{array}{l}25,1 \\
3,74\end{array}$ & $\begin{array}{l}26,3 \\
6,37\end{array}$ \\
\hline $\begin{array}{l}\text { № 2, середнє } \\
\text { станд. відхилення }\end{array}$ & 13 & $\begin{array}{l}17,3 \\
5,71\end{array}$ & $\begin{array}{l}17,8 \\
3,67\end{array}$ & $\begin{array}{l}28,2 \\
3,98\end{array}$ & $\begin{array}{l}18,5 \\
3,66\end{array}$ & $\begin{array}{l}23,1 \\
6,18\end{array}$ \\
\hline $\begin{array}{l}\text { № 3, середнє } \\
\text { станд. відхилення }\end{array}$ & 9 & $\begin{array}{l}32,3 \\
1,94\end{array}$ & $\begin{array}{l}23,5 \\
5,88\end{array}$ & $\begin{array}{l}18,2 \\
3,96\end{array}$ & $\begin{array}{l}15,8 \\
3,03\end{array}$ & $\begin{array}{l}15,1 \\
4,54\end{array}$ \\
\hline $\begin{array}{l}\text { Разом, } \\
\text { середнє } \\
\text { станд. відхилення }\end{array}$ & 60 & $\begin{array}{l}22,2 \\
6,29\end{array}$ & $\begin{array}{l}18,3 \\
5,17\end{array}$ & $\begin{array}{l}18,7 \\
6,21\end{array}$ & $\begin{array}{l}22,3 \\
5,24\end{array}$ & $\begin{array}{l}24,0 \\
7,21\end{array}$ \\
\hline
\end{tabular}

«Потреби» В.В. Скворцова з метою запобігання їі «старінню».

Цікавим і плідним було б також дослідження вираженості базових потреб студентів-психологів різних років навчання, яке б дало можливість встановити закономірності змін і розвитку потреб протягом навчання. Співставленні рівня задоволеності базових потреб студентів-психологів різних 3ВО, а також студентів психологів зі студентами інших напрямів підготовки дало б можливості прослідкувати взаємозв'язки між потребами та умовами життя та навчання студентів, специфікою обраного ними напряму фахової підготовки.

\section{ЛІТЕРАТУРА}

1. Майковская В.И. Изучение потребностей студентов как основа мотивации в услугах высшего образования. Учебный эксперимент в образовании : научно-методический журнал. Москва : ФГБОУ ВПО «Мордовский государственный педагогический институт им. М.Е. Евсевьева», 2015. № 1. C. 11-21.

2. Гончар Г.И. Формирование мотивации студентов институтов физической культуры к профессионально-прикладной физической подготовке : монография. Умань : ПП Жовтий, 2014. 238 с.

3. Щебельская Э.Г. Формирование культуры потребностей студентов вуза в педагогическом процессе. Известия Российского государственного педагогического университета им. А.И. Гериеен. 2009. № 112. С. 222-225.

4. Большедворская М.В. Анализ потребностей студентов вуза. М.В. Большедворская, Е.А. Соловьева. Успехи современной науки и образования. 2016. Т. 3. № 4. С. 134-138.

5. Рандовцева Т.Н. Исследование потребностей и мотивации студентов высших учебных заведений города Омска на основе пирамиды А. Маслоу. Перспективы и технологии развития педагогики и психологии. Сборник научных трудов по итогам международной научно-практической конференциии. № 3. Нижний Новгород, 2018. 59 с.

6. Крюкова Т.Б. Потребности и личностные особенности студентов. Альманах современной науки и образования. Тамбов : Грамота, 2007. № 1(1). С. 125-127.

7. Перепелкина Т.Е. Изучение степени удовлетворенности основных потребностей и системы ценностных ориентаций у студентов педагогического университета Альманах современной науки и образования. Тамбов : Грамота, 2007. № 7(7): в 2-х ч. Ч. І. С. 139-140.

8. Маслоу А. Мотивация и личность. СПб. : Питер, 2008. 352 с.

9. Тадеєва Т.В. Теорія самодетермінації Дісі-Раяна і навчальна мотивація. Наукові записки Тернопільського національного педагогічного університету імені Володимира Гнатюка. Серія: Педагогіка. Тернопіль, 2012. № 3. С. 213-221.

10. Беляева Л.А. Человек и его потребности. Учебное пособие. Екатеринбург : Урал. гос. пед. ун-т, 2009. $165 \mathrm{c}$.

11. Скворцов В.В. Способы разрешения конфликтов: методическая разработка. М. : АНХ при Совете Министров СССР, 1986. 46 с.

\section{REFERENCES}

1. Maykovskaya V.I. (2015) Izuchenie potrebnostey studentov kak osnova motivatsii v uslugakh vysshego obrazovaniya [The study of students' needs as a motivation basis in higher education services]. Uchebnyy 
eksperiment v obrazovani i: nauchno-metodicheskiy zhurnal. Moscow: FGBOU VPO 'Mordovskiy gosudarstvennyy pedagogicheskiy institut im. M. Ye. Yevseveva”, № 1, p. 11-21.

2. Gonchar G.I. (2014) Formirovanie motivatsii studentov institutov fizicheskoy kultury k professionalno-prikladnoy fizicheskoy podgotovke : monografiya [The formation of motivation of students of the institutes of physical culture for the professional-applied physical training : a monograph]. Uman : PP Zhovtiy.

3. Shchebelskaya E.G. (2009) Formirovanie kultury potrebnostey studentov vuza v pedagogicheskom protsesse [Formation of the culture of the needs of university students in the pedagogical process]. Izvestiya Rossiyskogo gosudarstvennogo pedagogicheskogo universiteta im. A.I. Gertsena, № 112, p. 222-225.

4. Bolshedvorskaya M.V. (2016) Analiz potrebnostey studentov vuza [Analysis of the needs of university students]. Uspekhi sovremennoy nauki i obrazovaniya, vol. 3, № 4, p. 134-138.

5. Randovtseva T.N. (2018) Issledovanie potrebnostey i motivatsii studentov vysshikh uchebnykh zavedeniy goroda Omska na osnove piramidy A. Maslou [The study of the needs and motivation of students of Omsk higher education institutions based on Maslows hierarchy of needs]. Perspektivy i tekhnologii razvitiya pedagogiki i psikhologii. Sbornik nauchnykh trudov po itogam mezhdunarodnoy nauchno-prakticheskoy konferentsii. Nizhniy Novgorod, № 3, p. 59.

6. Kryukova T.B. (2007) Potrebnosti i lichnostnye osobennosti studentov [Students' needs and personal features]. Almanakh sovremennoy nauki i obrazovaniya. Tambov : Gramota, № 1(1), p. 125-127.

7. Perepelkina T.Ye. (2007) Izuchenie stepeni udovletvorennosti osnovnykh potrebnostey i sistemy tsennostnykh orientatsiy u studentov pedagogicheskogo universiteta [The study of a level of satisfaction with the basic needs and a system of value orientations of the students of a pedagogical university]. Almanakh sovremennoy nauki i obrazovaniya. Tambov : Gramota, № 7(7), vol. I, p. 139-140.

8. Maslou A. (2008) Motivatsiya i lichnost [Motivation and personality]. SPb. : Piter.

9. Tadeieva T.V. (2012) Teoriia samodeterminatsii Disi-Raiana i navchalna motyvatsiia [Deci-Ryan's self-determination theory and educational motivation]. Naukovi zapysky Ternopilskoho natsionalnoho pedahohichnoho universytetu imeni Volodymyra Hnatiuka. Ser. Pedahohika. Ternopil, № 3, p. 213-221.

10. Belyaeva L.A. (2009) Chelovek i ego potrebnosti. Uchebnoe posobie [A man and his needs. A study guide]. Yekaterinburg : Ural. gos. ped. un-t.

11. Skvortsov V.V. (1986) Sposoby razresheniya konfliktov: metodicheskaya razrabotka [The ways of conflict resolution: guidance paper]. Moscow : ANKh pri Sovete Ministrov SSSR. 